\title{
Jack Burnham Redux: The Obsolete in Reverse?”
}

DOI:

10.1162/GREY_a_00205

\section{Document Version}

Accepted author manuscript

Link to publication record in Manchester Research Explorer

\section{Citation for published version (APA):}

Skrebowski, L. (2016). Jack Burnham Redux: The Obsolete in Reverse?". Grey Room, 64(Fall 2016), 88-113. https://doi.org/10.1162/GREY_a_00205

\section{Published in:}

Grey Room

\section{Citing this paper}

Please note that where the full-text provided on Manchester Research Explorer is the Author Accepted Manuscript or Proof version this may differ from the final Published version. If citing, it is advised that you check and use the publisher's definitive version.

\section{General rights}

Copyright and moral rights for the publications made accessible in the Research Explorer are retained by the authors and/or other copyright owners and it is a condition of accessing publications that users recognise and abide by the legal requirements associated with these rights.

\section{Takedown policy}

If you believe that this document breaches copyright please refer to the University of Manchester's Takedown Procedures [http://man.ac.uk/04Y6Bo] or contact uml.scholarlycommunications@manchester.ac.uk providing relevant details, so we can investigate your claim.

\section{OPEN ACCESS}


Jack Burnham Redux: The Obsolete in Reverse?

Luke Skrebowski

The emergence of a "post-formalist esthetic" may seem to some to embody a kind of absolute philosophy, something which, through the nature of concerns cannot be transcended. Yet it is more likely that a "systems esthetic" will become the dominant approach to a maze of socio-technical conditions rooted only in the present. New circumstances will with time generate other major paradigms for the arts.

- Jack Burnham, "Systems Esthetics" (1968)

In 1969 Robert Morris recommended that Patricia Norvell, then his graduate student in sculpture at Hunter College, interview the Chicago-based artist, critic, and theorist Jack Burnham in connection with her 1969 master's thesis on an emergent conceptual art. At the time Burnham was best-known for his recently published book Beyond Modern Sculpture: The Effects of Science and Technology on the Sculpture of This Century (1968)-in which he charted the evolution of sculpture's ontological ground from "object" to "system" on the model of a Kuhnian paradigm shift-and his Artforum articles "Systems Esthetics" (1968) and "Real Time Systems" (1969)-in which he generalized his analysis about the systematic character of recent sculpture to contemporary "unobject" art as a whole. 
Norvell was not in the end able to secure an interview with Burnham but did raise the question of the significance of his theory of systems aesthetics with several of the artists she spoke to, including Dennis Oppenheim, Robert Barry, Sol LeWitt, Robert Smithson, and Morris himself. Most of these artists responded favorably to Burnham's work, with the exception of Smithson and LeWitt. Smithson's evaluation was the most detailed and the most critical:

I don't see the trace of a system anywhere. That's a convenient word. It's like "object." It's another abstract entity that doesn't exist . . there are things like structures, objects, systems. But, then again, what are they? I think that art tends to relieve itself of those hopes. Like, last year we were in an object world and this year we're in a system world. . . Jack Burnham is very interested in going beyond and that's a kind of utopian view. The future doesn't exist, or if it does exist, it's the obsolete in reverse. . - I see no point in utilizing technology or industry as an end in itself or as an affirmation of anything. That has nothing to do with art. They're just tools. So if you make a system you can be sure that the system is bound to evade itself. So I see no point in pinning your hopes on a system. It's just an expansive object, and eventually that all contracts back to points. ${ }^{1}$

Smithson's critique of Burnham's work notes its technocratic technophilia ("I see no point in utilizing technology • • a as 
an end in itself"), teleogical orientation ("Like . . this year we're in a system world"), and utopianism ("Burnham is very interested in going beyond"). An astute and perceptive critic, Smithson's negative assessment of Burnham's work anticipated both the terms and the tone of subsequent judgments about the character and value of Burnham's theoretical oeuvre by influential art historians. Rosalind Krauss derogates Burnham's work as "technocratic"; Benjamin Buchloh deprecates "the limitations of a systems-aesthetic viewpoint"; and Thierry De Duve disparages Burnham as a potsmoking "utopianist of art's dissolution into life." ${ }^{2}$

What, then, might be gained by reading Burnham's work, written almost half a century ago, today? Such a question, while always potentially pertinent from a historiographical standpoint, is encouraged by the recent publication of a collection of Burnham's writing-Dissolve into Comprehension: Writings and Interviews, 1964-2004 (2016)-in MIT's prestigious "Writing Art" series. ${ }^{3}$ This volume represents an unlikely canonization of sorts for a figure whose work has long eluded mainstream art-historical acceptance and whose major works are no longer in print. Burnham's theory of systems aesthetics has, however, gained more favorable critical attention in recent years, being read principally in terms of its pioneering embrace of systems theory and cybernetics as productive discourses for the interpretation of art (Sabeth Buchmann, Michael Corris, Francis Halsall, Pamela M. Lee), its 
anticipation of new media art (Charlie Gere and Edward Shanken), and in relation to the influence of Burnham's systems thinking on Hans Haacke's work (Caroline Jones, Lee, and my own earlier writing). ${ }^{4}$ Yet Dissolve into Comprehension seeks to argue for the broadly based significance of Burnham's work as a whole, arguing that "his visionary theoretical ideas have only become more relevant in recent years" and that it is important to "restore his rightful place in art criticism and theory $\cdot{ }^{5}$

What then might we make of Burnham's corpus today? How to assess his "rightful place"? Was his near-term futurology just an instance of what Smithson, quoting Vladimir Nabokov, dismissed as "the obsolete in reverse" ${ }^{6}$ Or can a case be made for reversing its obsolescence? 


\section{The True Art Critic Helps the World by Revealing Mystic}

\section{Truths?}

In order to evaluate Burnham's work and assess the principle charges labeled against-that it is technocratic, utopian, and teleological-we need to understand its terms in ways that go beyond the reception it has hitherto received and what is comprehensible from a reading of Dissolve into Comprehension alone.

While Burnham (b. 1931) is still alive, he is in his mideighties, long retired, and has for some time lived a reclusive life, shunning publicity. As a result, new critical work of his own, or fresh pronouncements about his previous work on his own behalf, seem unlikely. Burnham's reputation as a writer thus rests on his existing body of work, the full breadth of which is represented in Dissolve into Comprehension. Burnham's oeuvre comprises two book-length monographs, Beyond Modern Sculpture: The Effects of Science and Technology on the Sculpture of This Century (1968) and The Structure of Art (1971); several catalogue essays (including short monographic studies on Haacke, Marcel Duchamp, and Komar and Melamid); a theoretical monograph on Herbert Marcuse published as the pamphlet Art in the Marcusean Analysis (1969); and numerous articles, interviews, and reviews published from 1964 to 1990 (with the great majority appearing from 1964 to 1981) in art magazines including Artforum, Arts, 
The New Art Examiner, and Art in America, or as chapters in collections (a selection of these articles, written up to 1973, was anthologized in Burnham's 1974 book Great Western Salt Works: Essays on the Meaning of Post-formalist Art). ${ }^{7}$ Since 1973 Burnham has also been working on a projected monograph interpreting the art and writings of Duchamp. Although unpublished, its outlines were set out in a series of articles on Duchamp written from 1971 to 1973 for various art magazines (some of which were collected in Great Western Salt Works ) •

The most productive period of Burnham's career as a theorist was thus relatively compressed, running from the mid1960s to the mid-1970s. This period can be schematized into four distinct moments involving three significant theoretical turns.

1. A History and Theory of Modern Sculpture (1964-1967)

In Beyond Modern Sculpture (1968) Burnham set out to provide a materialist, avowedly technologically determinist, study of the development of modern sculpture from the $1870 \mathrm{~s}$ to the 1960s. His account was teleological, distinguishing between an earlier and residual conception of "sculpture as object" and a later, still-emergent, conception of "sculpture as system." He predicted that sculpture would eventually evolve into a living system (thus collapsing the separation between the representation and the production of life), in concert with 
the broader emergence of a posthuman future characterized by the dominance of synthetic over organic life.

2. An Account of Contemporary Art (1967-1970)

In "Systems Esthetics" (1968) and his other essays on the topic of systems and aesthetics-including "Systems and Art" (1969), “Real Time Systems" (1969), Art in the Marcusean Analysis (1969), "The Aesthetics of Intelligent Systems" (1970), and "Notes on Art and Information Processing" (1970)Burnham generalized his earlier claims about the shift of a single medium from an object-based to a systems-based ontology to art in general (hence systems aesthetics) while simultaneously dropping the teleological aspects of Beyond Modern Sculpture, insisting that the paradigm shift represented by the emergence of a systems aesthetics would itself likely be superseded.

3. A Theory of Modern Art (1970-1972)

In The Structure of Art (1972), written as a thoroughgoing response to criticisms levelled at Beyond Modern Sculpture and in light of the failure of his exhibition Software, Information Technology: Its New Meaning for Art (1970) to convincingly demonstrate systems aesthetics in practice, Burnham converted to structuralism as a new and more effective way to clarify the ontology of modern art, now understood as an overarching signifying system. Here Burnham sought to combine structural anthropology and semiological analysis (both derived from Saussurean structural linguistics) to 
produce an account of the underlying, synchronic, structural logic of modern art (1840s-1970s). Burnham modeled his new approach on Claude Lévi-Strauss's exploration of the underlying logic of myth in traditional cultures but translated it to an analysis of "Western art" (thereby also challenging anthropology's Eurocentrism).

4. A Hermetic Theory of Art (1972-ongoing)

In his work on the structural logic of modern art, understood to be in an end-game state, Burnham came to regard Duchamp's work as exemplary, finding in the Large Glass and the readymades an exemplification of the logical semiotic structure of all forms of art. Burnham also became convinced that Duchamp was a hermeticist who had covered up the true meaning of his art. Burnham consequently sought to reveal the meaning of Duchamp's work, and thus of art tout court, by engaging with various esoteric traditions as interpretative methodologies, principally Kabbalah. Burnham combined these esoteric readings with structuralism in the remainder of his work, which is characterized by an arcane mysticism that did not find a ready audience. Representative texts of this phase include "The Semiotics of 'End-Game' Art" (1972), the threepart “Duchamp's Bride Stripped Bare" (1972), “The True ReadyMade" (1972), and "Voices from the Gate" (1972).

Dissolve into Comprehension is organized in a broadly chronological order and subdivided into four thematic sections: Sculpture, Systems, Art Worlds, Arcana. The 
anthology collects a series of Burnham's major articles, including all of the systems essays and one of the Duchamp ones. Burnham's book-length monographs Beyond Modern Sculpture and The Structure of Art are represented by extracts from their introductions. Art in the Marcusean Analysis is included in abridged form. The anthology also breaks new ground by including an important early draft of "Systems Esthetics" entitled "Towards a Post-Formalist Aesthetics" and helpfully includes an example teaching syllabus (Burnham's work as a teacher informed his theoretical work, which also fed back into his teaching). A couple of interviews with Burnham and a curriculum vitae circa 1981 round out the picture of Burnham's oeuvre and intellectual trajectory.

Notwithstanding the fact that the selections from Beyond Modern Sculpture and The Structure of Art are so short-four pages and three pages respectively-as to give scant sense of these books' stakes and significance, this is a welcome anthology that puts the full range of Burnham's work before us once more. ${ }^{8}$ An acute survey essay and section introductions by the editor of the volume, Melissa Ragain, set out the character of Burnham's intellectual trajectory, not shying away from the difficulties inherent in it.

Yet what Ragain does not thematize is the question of why Burnham's work underwent such radical theoretical turns in such a relatively short space of time. Burnham's thought was uneven and mercurial, starting in scientific rationalism and 
ending in esoteric irrationalism. Dealing with this issue is a necessary propaedeutic to any evaluation of the contemporary value of his work. Burnham discussed a range of issues in his earlier writing that remain live today and which argue for his ongoing relevance. These include his attention to the fraught relationship between art and technology (a major fault line in contemporary culture, echoing in the highly contested debates around new media art, Net and post-Internet art, and retrotechnofetishism); his pioneering consideration of the use of artificial intelligence and biological engineering in and as art (even if we are no longer persuaded by the idea that these engagements will define art's telos); the artistic relevance of systems theory and cybernetics (both in the historicization of late modern art and for contemporary art theory); and the need for a coherent ontology of contemporary art (addressed in ongoing debates about the emergence of "the contemporary" as a critical category that can replace postmodernism). And yet Burnham's work suffers from an awkward elision of humanistic and scientific traditions of thought, and his later writing is characterized by an esotericism that disqualifies it from conventional academic validity. ${ }^{9}$

By the time of writing the introduction to Great Western Salt Works in 1974, Burnham openly acknowledged his own "psychological metamorphosis" and the apparently jarring contrasts that characterized his theoretical project: “given the quasi-scientific rationalism implicit in the first few 
systems essays, the gradual transition toward high magic in cabalism and alchemy appears to be a complete inversion."10 Yet Burnham explained the links connecting the theoretical turns in his thought: "the systems view of reality, with its theory of hierarchies and fusion of living and nonliving structures, is not inconsistent with hermetic philosophy."11 He also clarified what he took to be the limitations of systems theory for constructing a theory of art, noting that its

"utilitarianism and obsession with efficiency leave much about organic relationships misunderstood. Ultimately systems theory may be another attempt by science to resist the emotional pain and ambiguity that remain an unavoidable aspect of life." ${ }^{12}$ In Great Western Salt Works Burnham projected a new iteration of his project, inspired by his work on Duchamp, that would involve developing a full-blown "hermetic theory of art."13

Burnham thus produced a coherent, if not necessarily persuasive, rationale for the evolution of his thought. His embrace of irrationalism should not, therefore, simply be dismissively pathologized (or passed over in quiet embarrassment) as an example of what Michel Foucault describes in Madness and Civilization as "reason dazzled" (Burnham's writing on nonmystical topics in articles written after his esoteric turn is perfectly lucid). ${ }^{14}$ Here I am in accord with Ragain, who asserts that for full comprehension of Burnham's work "historians [should] no longer efface the mystical turn of Burnham's later career" (although her claim that the turn 
can be addressed "as an extension of the self-organizing and determining nature of systems and their not-so-distant relation to historical notions of 'spirit' or 'mind'" is less convincing since Burnham explicitly compared systems theory to "hermetic," rather than Hegelian, philosophy and the notion of autopoiesis finds little conceptual resonance with the dialectic) $\cdot{ }^{15}$

While I will argue that only the second "systems aesthetics" phase of Burnham's work proves to be ongoingly productive, that phase needs to be contextualized in light of the full development of his thought, including his latercareer embrace of esotericism. This final phase was not simply a case of New Age burnout (however unrewarding its artistic readings might appear to noninitiates). Rather, it resulted from an attempt to reconcile the tensions that marked his artistic and theoretical project, which sought to fuse art and technology and thereby resist the "disenchantment of the world" effected by modernity as diagnosed by Max Weber via Friedrich Schiller. Burnham's eventual mysticism was a result of the persistent frustration of his syncretism.

\section{Becoming "Jack Burnham"}

Burnham is now best known as a theorist, but he started his career as an artist. This fact is noted by Ragain in her introduction to the first section of Dissolve into Comprehension, where she comments on his training at the 
Boston Museum School, beginning in 1953, where he also struck up an influential friendship with Naum Gabo, who was then teaching at the Graduate School of Design at Harvard (Burnham dedicates the new volume to "my mentor Naum Gabo"). What Ragain does not mention specifically (the information may be gleaned from Burnham's curriculum vitae, which Ragain includes in the volume), is that Burnham also trained as an engineer, in this respect explicitly resembling his "mentor."16 His engineering training is thus material to a thorough understanding of his artistic and intellectual formation. Burnham split his studies at the Boston Museum School of Fine Arts (majoring in commercial design and silversmithing, with minors in sculpture and painting) into two phases-19521954 and 1956-1957. During the intervening two years, he studied for an engineering associate's degree in architectural construction at the Wentworth Institute in Boston in 1954-1956 (then, as now, a vocationally oriented college). Burnham subsequently went on to study at the Yale School of Art, taking a bachelor's of fine arts in 1959 and a master's of fine arts in 1961. Burnham's training was thus distinctively hybrid, combining art and the (applied) sciences, the practical and the fine arts.

Burnham's work was shaped by his relationship with the deradicalized "Cold War constructivism" propagated by Gabo (to employ Benjamin Buchloh's insightful coinage) as well as by a broader engagement with the reformulated postwar terms of the 
historic avant-gardes as influentially disseminated in the United States via the New Bauhaus refounded in Chicago. ${ }^{17}$ Burnham records that "a design course" he had taken in the early 1950s "under one of Kepes' and Moholy-Nagy's protégés at the Chicago Bauhaus" proved "extremely influential" for his developing "interest in luminous art and Russian Constructivism."18 Later, in 1957, after he had completed his studies in architectural engineering at the Wentworth Institute, Burnham states that he attended a "seminar on emitted light as an art form" given by György Kepes himself to architectural students at MIT and that this "gave me things to ponder."19 Burnham also notes that he went through Josef Albers's "Bauhaus pedagogy" at Yale. ${ }^{20}$

Although Burnham did not take any of his degrees from the New Bauhaus itself, his formation was very much in the spirit of its reformed U.S. Vorkurs, incorporating specialized scientific and technical training alongside more traditional instruction in art and design. Burnham's bildung was then distinctively New Bauhausian, in both its Moholy-Nagian design institute and Albersian liberal arts inflections (albeit with little engagement in the Dada-inflected strand of this tradition that proved so fertile at Black Mountain and that would later spread to New York, inspired by the college's teaching and summer courses), and this determined the artistic problems he addressed in his early practice as a kinetic sculptor. 
Burnham worked as an artist from 1954 to 1968 but supported his practice by a mixture of full- and part-time employment as an architectural draftsman and designer (19571958), as a corporate sign fabricator and painter (1956-1968), and as an educator (1959-1968). Although Burnham had five oneman shows from 1965 to 1969 and participated in several group shows from 1957 to 1978 (with most concentrated from 1965 to 1970), none of his solo shows (and only one of his group shows) were in New York, and his career as an artist did not take off. He began teaching as an assistant professor of art at Northwestern University in 1964, having also served as an instructor at Yale, Wesley College and Northwestern from 1959 to 1964 .

Burnham subsequently worked principally as an art educator, theorist, and critic, holding a contributing editorship at Artforum (1971-1972), an associate editorship at Arts (1972-1976), and a contributing editorship to New Art Examiner (1976-1983), while progressing from assistant to associate professor of art at Northwestern in 1969 and to full professor by 1974 before transferring to the University of Maryland as chair of the art department in the 1980s, where he taught until his retirement. ${ }^{21}$

What has not been discussed elsewhere in the existing scholarship on Burnham, as far as I am aware, is the fact that after graduating from high school in 1949 Burnham spent four years in the U.S. Army at Fort Belvoir (1949-1952) in the 
drafting school of the Corps of Engineers. ${ }^{22}$ Although Burnham did not serve in the Korean War (1950-1953) he nonetheless undertook military service at the inception of the Cold War, under the then recently announced, newly interventionist Truman Doctrine, which promised to provide American economic and military assistance to any democratic nation threatened by authoritarianism (which at the time, given the collapse of National Socialism, meant principally Soviet- but also Chinese-backed Communism).$^{23}$

Burnham's professional formation thus began within, and proceeded through, a full set of constituent institutions of a nascent U.S. Military-Industrial-(Educational) Complex, friendly to radical innovation in the means of production but hostile to any corresponding innovation in its social relations-and still more so to its mode. Burnham's early exposure to, and engagement with the "Bauhaus and related ideals" under the Cold War pressure of political neutralization profoundly shaped the subsequent development of his artistic practice and thinking.

Yet although Burnham was manifestly formed in and by the postwar technocracy, to consider his intellectual work as if it were completely overdetermined by its context would be a mistake. Just as Jones has adeptly traced the complex processes by means of which "Clement Greenberg" was constructed, but also constructed himself, as a subject in relation to the development of a particular version of 
modernism (understood in terms of the sensory priority of vision) and modernity (conceived in terms of a bureaucratization of the senses), so I want to pursue a similar, although here necessarily much slighter, critical history of Burnham's subjective formation in relation to modernism (understood in terms of a New Bauhausian attempt to reconcile scientifico-technical and artistic culture under U.S. capitalism) and modernity (understood in terms of the ramifications of technocracy) ${ }^{24}$

Burnham was subjectivated by technocracy but also sought to mold his artistic and intellectual subjectivity in complex forms of negotiation with it, in terms of negation as well as of affirmation. By the time he undertook a one-year fellowship at the Center for Advanced Visual Studies (CAVS) at MIT under Kepes in 1968, Burnham was, by his own retrospective account from 2004, "trying to get away from the Constructivism of Naum Gabo" and also "in full revolt against Kepes' 'New Bauhaus' philosophy."25 One of the principle points of contention for Burnham was Kepes's failure to engage with the advanced, computerized, technology of a dawning second machine age: “[E]xcept for those areas of scientific research that produced stunning photographs . . Kepes had a strange aversion to direct involvement with sophisticated technology, particularly anything to do with the computer sciences." ${ }^{26}$ In failing to keep pace with its latest developments, Kepes, for Burnham, 
automatically sacrificed the possibility of technology's progressive reorientation.

In direct contrast to Kepes's stance, Burnham spent his time at CAVS engaged in conversations with two computer scientists (Oliver Selfridge and Jack Nolan) and "working on an essay on the use of computers in art making" (which would be published as "The Aesthetics of Intelligent Systems"). ${ }^{27}$ Burnham also focused on his own artistic practice, making a "light environment involving programmed electronics and computer components" that employed "electroluminescent tapes" predominantly used by the military for “instrument panels, safety lights, and temporary helicopter landing beacons in Vietnam" that Kepes had secured via an "alliance with Sylvania Corporation." ${ }^{28}$

Burnham's Sylvania Tape works, photographs of which are reproduced in Dissolve into Comprehension, were, however, awkward constructions that can plausibly be charged with failing to gain any meaningful critical purchase on their matériel and thus of fetishizing technology and being technocratic in a reactionary sense. Consequently, we may have reason to question how successful Burnham's self-declared "revolt" against Kepes's and broader New Bauhaus principles actually was at the level of his practice.

Yet the significance of these works within Burnham's oeuvre inheres precisely in their lack of success as meaningful art and their failed reception, acknowledged by 
Burnham himself: "I could not give the systems works away, much less sell them." ${ }^{29}$ In fact, the Sylvania Tape constructions that Burnham worked on at CAVS represent not only the concluding moment of his electroluminescent work (begun in 1966) but of his artistic career as a whole. ${ }^{30}$ After his CAVS placement Burnham stopped making art.

By considering the failure of Burnham's own artistic practice, confirmed by its cessation, we can gain deeper insights into the stakes of his historical and theoretical writing. Beyond Modern Sculpture, completed in 1967 but not published until 1968, can and has been read as a pioneering attempt to articulate a history of the development of modern sculpture in relation to technological change. Yet the book should also be read as contextualizing the artistic problems that Burnham attempted to deal with in his own art practice. This can be inferred from Burnham's revealing inclusion of a brief description of his own work within this history, under the heading of "Recent Use of Light in American Art": In 1954 the author began to use incandescent light as back lighting for various wood and cardboard reliefs. The author's first experiments with neon light were begun in 1955, partly as a result of Kepes's example. The work shown is one of a series of hanging constructions using neon created during the 1950s. - . Subsequent projects, beginning in 1959, have included experiments in photo-kinetics, or light motion phenomena. These include light walls using the principles of 
apparent motion, color-modulating consoles using fiber-optic wires (i.e. light-transmitting wires), and programmed constructions using electroluminescent Tape-Lite. ${ }^{31}$ This modest, descriptive paragraph is illustrated with a single image of his 1956 work Atom. Nonetheless, it demonstrates the coterminous character of Burnham's artistic and intellectual work in the early part of his career. After his CAVS fellowship, and in light of his recognition of the limitations of his own practice (as well as in response to criticisms levelled at Beyond Modern Sculpture that came in from 1968 onward), Burnham decisively broke with teleological conceptions of advanced art as well as with what he describes as the "romanticization of technology" marking the New Bauhausian project. ${ }^{32}$

Nonetheless, Burnham continued to pursue the same artistic problems he had previously directly worked on, only now by the proxy means of his writing and teaching practice. After ceasing to make art of his own, Burnham turned in his "systems essays" to a concerted attempt to theorize what he took to be successful contemporary art. In these essays Burnham attempted to combine systems theory and Marcusean critical theory in a post-(New) Bauhausian project to better characterize the stakes and achievement of vanguard practice. Here Burnham was interested to explain contemporary art that resisted a reactionary technocracy while not shying away from 
the implications he believed the dawn of informational technology would hold for art.

\section{Systems Aesthetics}

Although recent scholarly attention has been addressed to the "systems" aspect of Burnham's systems aesthetics, almost nothing has been made of its specifically aesthetic claims. Burnham sought to develop systems aesthetics as a general theory of contemporary artistic production, an aesthetics in the traditional sense, avoiding movement-specific categorization. As he writes, "The notion of a 'Systems Esthetics' appeared to have validity as momentum built up for Earth Art, Ecological Art, Body Art, Video Art, and the multitudinous forms of Conceptualism." ${ }^{33}$ Burnham's notion of a systems aesthetic involved more than just an investment in then-current forms of systems thinking (systems theory, cybernetics, and information theory). Rather, it held an explicitly aesthetic character in the strong philosophical sense of the term, one derived from Burnham's adoption and adaptation of Herbert Marcuse's work, specifically Marcuse's neo-Schillerian rethinking of the possible relation between aesthetic and technocratic reason.

While Theodor Adorno refused utopian speculation, Marcuse proposed an aestheticization of technique as a possible, socially transformative, response to the dialectic of enlightenment and the domination of technocratic reason. This 
argument about an aestheticization of technique is precisely what Burnham picked up on in Marcuse's work. Rejecting Greenberg and Fried's postformalist aesthetics, he attempted to produce a reformulated account of the vanguard art of the late 1960s as aesthetic, but an aesthetic far removed from Greenberg and Fried's formalism.

Indeed, Burnham had originally planned to give "Systems Esthetics" a different title-“Towards a Post-formalist Esthetic"-but was persuaded by Philip Leider, then editor of Artforum (and also at that point a strong ally of Fried's), to amend his title and to cut substantial parts of his opening polemic against formalist aesthetics. (Melissa Ragain productively recovers the facts surrounding the composition and publication of "Systems Esthetics" in her introduction to Dissolve into Comprehension, and her inclusion of Burnham's original version of the article in the new volume, albeit abridged, is particularly valuable).$^{34}$

While it is not clear that Burnham's systems aesthetics fully succeeded in grounding the ontology of the art that it purported to specify, the significance of his postformalist move to embrace systems theory was highly prescient, anticipating the methodological diversity of the new art history as well as of postconceptual art. In "Systems Esthetics" Burnham called upon Ludwig von Bertalanffy's work to furnish a definition of art as a system, a "complex of components in interaction." Even though this was a relatively 
loose claim, disqualifying nothing more than the minimalist "specific object" and art made in the traditional mediums, it was also highly ambitious, setting out to grasp the nature of nascent forms of post-object-specific art in the expanded field (particularly performance and installation). Indeed, Burnham's systems aesthetics attempted to define "unobject" art by way of a relational ontology thirty years before Nicolas Bourriaud's claims about art exhibiting a relational aesthetic: "the specific function of modern didactic art has been to show that art does not reside in material entities, but in relations between people and between people and components of their environment"; "conceptual focus rather than material limits define the system." ${ }^{35}$

Burnham's theory of systems aesthetics is often read only as it was articulated in his 1968 essay "Systems Esthetics," but his project for a postformalist aesthetics was in fact articulated across all of his systems essays and developed in dialogue with his artistic practice and teaching. ${ }^{36}$ "Systems and Art" (1969) recounts Burnham's experience giving an Art and Systems course at Northwestern. ${ }^{37}$ His course principles derived from the frustrations he had found when previously trying to teach students to make kinetic art (his own métier as a luminist artist). Burnham insisted that "the essential task lies in defining the aesthetic implications of a technological world" and noted that the Bauhaus-derived, but politically neutered, industrial-era pedagogic methods that 
were then being used in the United States were not up to the task. ${ }^{38}$ Burnham instead seized upon the "systems analysis and design approach to problem solving" as an alternative methodology that could be applied to his teaching. ${ }^{39}$ Although he recognized that systems analysis was tainted by its association with the Military-Industrial Complex (he referred to it as being understood to possess an “icy Pentagon-esque logic"), Burnham was nevertheless convinced that "the systems approach" seemed to be "the one technique which can embrace an understanding of the span of present-day technology and its consequences" and noted its contemporaneous application in pacific fields, including “conservation, pollution control, and human ecology." 40

Burnham's broader pedagogical aim was, he wrote, to achieve a "future rapproachment [sic] between art and technology" but his malapropism here-conflating the opposed senses of the French rapprocher ("to bring [something] closer") and the English reproach ("to express disapproval")functions as a Freudian slip that discloses the tensions that marked his theoretical project. ${ }^{41}$ And, indeed, rather than defining art, Burnham's systems aesthetics seemed more interested in pursuing an argument for its dissolution: "In an advanced technological culture," Burnham claimed, "the most important artist best succeeds by liquidating his position as artist vis-à-vis society. ${ }^{42}$ 
This ambition to dissolve the distinction between art and technology led Burnham to Marcuse's work. In Art in the Marcusean Analysis (1969) Burnham comments in detail on his reading of Marcusean critical theory, and from this text we can trace the influence that Marcuse exerted on his work. ${ }^{43}$ Excepting Ragain's relatively brief discussion of Art in the Marcusean Analysis in Dissolve into Comprehension, Marcuse's intellectual influence on Burnham has passed almost unremarked in the existing scholarship. ${ }^{44}$ Art in the Marcusean Analysis consists of an extended exegesis and critical commentary on Marcuse's thought up to 1968 , largely focused on his aesthetics. ${ }^{45}$ Burnham not only drew on Marcusean theory but also attempted to remedy what he considered to be its deficiencies. To this end, Burnham took up Marcuse's insight about art's resistance to technological rationality and its possible role in effecting an aestheticization of technique, but turned it into his own stronger and more deterministic claim that "art will become an important catalyst for remaking industrial society."46 Burnham correctly observes that "the emergence of an artistic technology rather than the emphasis on technical art" is "the essence of Marcuse's hopes," yet he also objects that "somehow Marcuse, a master of the dialectic, never consciously comes to the conclusion that newer media are the critical instruments of social liberation."47

Here Burnham reveals his own hopes, claiming that "a fusion of artistic and technical reason" was "inevitable" once 
art ceased "to function as illusion and ideal appearance." 48 Yet in making such a claim Burnham misunderstands Marcuse's speculative, neo-Schillerian claims for the potential sublation of technological rationality by aesthetic rationality, mistakenly arguing for the possibility of "synthesis" between incompatible rationalities under actually existing postwar capitalism: “His [Marcuse's] most subtle speculation is directed towards the traditional antipathy between art and technology . . the dialectical synthesis becomes a technology based on esthetic values." ${ }^{49}$ Optimistically venturing the critique that "Marcuse fails to recognize. - that cultural forces of assimilation are just as often assimilated by forces which they have sought to engulf," Burnham misses, or chooses to ignore, Marcuse's clear-eyed recognition that "Art as a form of reality' means not the beautification of the given, but the construction of an entirely different and opposed reality. The aesthetic vision is part of the revolution." 50

Burnham thus deradicalizes, whether wittingly or not, Marcuse's political claims and misunderstands his aesthetic ones. He argues for a process of artistically led social reform, rather than revolution, and thinks this might be achieved by the fusion of art and technology. Nonetheless, Burnham's work engages an important tradition of Left Technocracy, stemming from Karl Marx's reading of the fragment on the machines in the Grundrisse and developed by Marcuse in 
the United States (a tradition that has also inspired more recent attempts to rethink the possibility of a shift to “postcapitalist" production). ${ }^{51}$ Thus Burnham's systems aesthetics, despite its theoretical shortcomings, offers suggestive resources for attempts to rethink the possible relations between art and technology in a progressive manner.

Burnham's misunderstandings were, however, compounded in the exhibition he curated at the Jewish Museum in 1970 sponsored by the American Motors Corporation: SoftwareInformation Technology: Its New Meaning for Art. Here he presented advanced art and advanced technology within the same institutional and conceptual frame-his curatorial rationale was inspired by the same attempted fusion of Marcuse and systems theory that underlay his theory of systems aesthetics. As he wrote in his catalogue essay, "Notes on Art and Information Processing," "Software makes none of the usual qualitative distinctions between the artistic and technical subcultures. At a time when esthetic insight must become a part of technological decision-making, does such a division still make sense?" ${ }^{52}$

Burnham's attempt to prevent his theory of systems aesthetics from being conflated with the ideology of an increasingly marginalized tech art was also an undercurrent that informed the show, in part inflamed by a spat he had entered into in Artforum in 1969 with the critic Terry Fenton, who had accused Burnham's position of amounting to little more 
than a rehash of (postwar) constructivism's misguided technoscientific enthusiasms. ${ }^{53}$ Burnham's response was telling: "Again and again I have stressed the need not for TekArt-that new hobgoblin of the critics-but for a technology based on aesthetic considerations. Where the latter exists the art impulse will take care of itself."54 And Burnham insisted in his catalogue essay that "Software is not technological art; rather it points to the information technologies as a pervasive environment badly in need of the sensitivity traditionally associated with art."55 Burnham, however, struggled to convincingly convey the coherence and the validity of his curatorial premise, and his show met with considerable controversy, being widely critically panned and accused of complicity with the Military-Industrial Complex. Reflecting on the negative reception of Software in an interview with Willoughby Sharp later in 1970, Burnham reserved some sharp words of his own for the hypocrisy of much of the New York art world:

In the last few years, Maurice Tuchman, Kepes at MIT, and myself among others have used money from visible outside sources, electronics companies and such. So the artist is put in the compromising position of making pieces with money whose source he knows. Somehow the fact that the Guggenheim Foundation's grant come [sic] from the copper mines of South America doesn't bother artists half so much as openly working with American Motors. ${ }^{56}$ 
Yet the major problem with Burnham's show was not compromised ethics, as many critics charged (Burnham had a valid rejoinder to make about the art world's sources of institutional funding), but rather its voluntarism. He attempted to simply produce (or, on a more charitable interpretation, agitate for) his hoped-for fusion of aesthetic and technological reason by juxtaposing cutting-edge art and bleeding-edge technology, without recognizing the impossibility of his hope for the resolution of the contradictions between their competing rationalities under actually existing social conditions. This fundamental aporia in his thinking shortly led Burnham to jettison the philosophically inspired project of his systems aesthetics altogether. Nonetheless, Burnham maintained an interest in systems thinking and turned to structuralism as a methodology in his second book, The Structure of Art (1972), which announced the third phase of his theoretical project, an attempt at a unified, general theory of modern art (with art's underlying, synchronic, structural logic understood by analogy with myth): Esthetic doctrines once proclaimed that art was "beauty," "the search after truth," or "significant form"; what passes for esthetics today-that lingering element which makes art art-is no more helpful. Like the patient who repeatedly relocates the cause of his neurosis while being careful never to divulge its underlying origins, redefinition diverts us from the structure 
of art. . . Our purpose . . is . . a structural definition of art. ${ }^{57}$

Burnham's second book is an unpersuasive text, beset by its project to equate modern Western art with myth and hobbled by an attempt to apply the same unconvincing and inflexible structural schema across a wide array of sharply divergent case studies, from J.M.W. Turner's Rain, Steam and Speed (1844) to Daniel Buren's Photographic Souvenir of one of the Pieces Executed in Kyoto, Japan (1970). In short orderinspired by his work on putatively hermetic aspects of Duchamp's work that emerge in his chapter on the artist in the book-Burnham began to supplement the limited interpretive schema he mobilized in The Structure of Art with categories drawn from Kabbalah and other esoteric sources.

This final turn inaugurated the fourth and concluding phase of Burnham's intellectual project, wherein he set out to produce a hermetic theory of art via his projected book on Duchamp as an esoteric key to the logical semiotic structure of all forms of art. I am not able to comment on the accuracy of Burnham's work drawing on esoteric traditions, but the deeply unpersuasive readings of particular artists and works that they advance militate against according them historical value. ${ }^{58}$ Rather, I propose that Burnham's late hermeticism is best understood as symptomatic; it is a reaction to, and a final attempt to resolve, the fundamental aporia that marked 
his work and that he did not resolve by attempting to mythify modern art in The Structure of Art.

Support for this argument can be found in Burnham's important late essay "Art and Technology: The Panacea That Failed" (1980), which qualifies his esoteric turn, revealing it to be an attempt at a mystical reenchantment of the world, a reenchantment that Burnham had failed to achieve in his earlier Marcuse-inspired project to reconcile aesthetic and technological rationality. In "Art and Technology" (unfortunately not included in Dissolve into Comprehension) Burnham explores the reasons why, as he frankly describes it, "science has spawned a wealth of technical gadgetry, while. . - modern visual artists have been notoriously unsuccessful in utilizing much of it in the making of socially acceptable art." ${ }^{59}$ Burnham begins his argument by reflecting on the limited number of exceptions to the broad failure of art and technology. These include Alexander Calder and George Rickey's kinetic sculpture, the "unexotic fluorescent fixtures" of Dan Flavin's "luminous sculpture," Haacke's "water boxes," Takis's Signals, and Jean Tingueley's “fantastic robots and constructions." ${ }^{60}$ Burnham then goes on to assess five major art and technology projects initiated in the 1960s: Billy Klüver and Robert Rauschenberg's "Experiments in Art and Technology," Jasia Reichardt's Cybernetic Serendipity exhibition, Burnham's own Software exhibition, CAVS, and the Los Angeles County Museum of Art's "Art and Technology" initiative. 
Burnham has incisive, local points to make about aspects of these projects, all of which he considers limited. His conclusion about the overall failure of art and technologybased practice, however, is particularly revealing: "Have they failed as art because of technical or esthetic incompetency, or because they represent some fundamental dissimilarity as systems of human semiosis? Although it is clear that technical incompetency is partly to blame, I would suspect the latter is a more fundamental explanation."61 Burnham here reveals the tensions that mark his own thought as much as any fundamental truth about the relationship between art and technology (compare, for example, the ambiguity of techné, and its entanglement with poiesis, for Martin Heidegger in "The Question Concerning Technology") ${ }^{62}$

He then narrates his own consequent turn to myth as an alternative explanatory schema adequate to "systems of human semiosis" (here glossed with reference to Roland Barthes book Mythologies, orignally published in 1957 but first published in English translation in 1972 Burnham remarks on the challenges he found in attempting to transpose Barthes's semiology to art, noting that it offered "insufficient insight into the dynamic vicissitudes of . . more complex phenomena."63 He concludes the essay by commenting on the metaphysical insights about art that this recognition of semiology's limitations led him to: 
Western art . . contradicts Barthes' everyday mythic invisibility because art by its very paradoxical nature (its near perfect resistance to economic, psychological, or sociological interpretation), openly signifies an apparent mystery concerning the fusion of spirit and matter. So at the highest level, secrecy and a code of concealment are imperative for its cultural survival. ${ }^{64}$

In "Art and Technology: The Panacea That Failed," Burnham narrates the way in which the fundamental aporia that characterizes his artistic and intellectual work-the tension between art and technology, aesthetic and technological rationality-came to be "resolved" by his later-career recognition that art was to be understood as a set of secret codes that conceal its "fusion of spirit and matter." This mystical understanding of art leads Burnham to turn to esoteric interpretation, inspired by a new faith in an ability to reenchant the world by revealing veiled truths.

\section{Modernism's (Other) Nervous Breakdown}

Revisiting the criticisms of Burnham's work as technocratic, teleological, and utopian, first levelled by Smithson in 1969 and echoed by leading art historians since then, we can see that they hold a measure of truth but also an equal measure of inaccuracy. Burnham's technophilia was tempered by his critique of reactionary technocracy. He produced a teleological account in Beyond Modern Sculpture in 1968 but 
had renounced this aspect of his work by the time he published "Systems Esthetics" later that same year (thus Smithson's critique of Burnham's teleological thinking was already inaccurate at the time it was made). The charge of utopianism is perhaps most apposite-and certainly more forgivable, if not potentially laudable-but Burnham's secular political hopes for a fusion of art and technology were displaced into an otherworldly mysticism and were thus also a passing aspect of his project.

The character, and the associated value, of Burnham's work does not come, therefore, from his maintenance or development of any one coherent methodological approach or theoretical position. Rather it issues from his prescient and determined commitment to produce a postformalist account of the ontology of art and its associated, highly creative, although often problematic, theoretical syncretism. Haacke, a long-standing friend and interlocutor of Burnham, accurately captures both aspects of Burnham's work in his preface to Dissolve into Comprehension:

Jack's was not the kind of art criticism based exclusively on an art historical and humanist foundation. Instead, his interdisciplinary approach drew from a wide range of disparate fields that were normally not connected. It opened a new understanding of that peculiar, socially negotiated phenomenon referred to as "art," and it explicitly challenged the 
formalist doctrine, which held considerable sway at that time. ${ }^{65}$

The legacy value of Burnham's work comes from the specific theoretical syncretism, and the innovative postformalist aesthetics, represented by the second phase of his work; namely, the account of the ontology of contemporary art, articulated in relationship to technology, offered by his theory of systems aesthetics.

Burnham was the first to attempt a substantive critique of Greenberg and Fried's formalist position in the U.S. context (innovatively mobilizing methodologies taken from outside the humanities to do so) as well as the first to venture a comprehensive theoretical alternative to it, anticipating the antiformalism of artistic postmodernism. His postformalist aesthetics tried to combine Marcuse's neoSchillerianism with systems theory and cognate disciplines, but the structural contradictions of this project proved intractable, resulting in a failed syncretism that exerted its own psychic cost.

Systems aesthetics might thus be historicized as the "nervous breakdown" of the New Bauhausian modernist tradition that Burnham failed to extend for an age of advanced technology ${ }^{66}$

As a result, Burnham might now look like a transitional figure in the history of ideas. Yet Burnham's project (if not its specific methodological articulation) is relevant again 
today because of the way in which it throws into relief the narrowly anti-aesthetic and often technophobic shortcomings of its principle successor. Postmodernist accounts of art were deeply overdetermined by (the breakdown of) Greenberg's narrow, aesthetically formalist conception of modernism, as Jones and Peter Osborne discuss and Hal Foster himself has recently acknowledged. ${ }^{67}$ Artistic postmodernism was constructed for the most part-notwithstanding the importance of John Cage's "minor" (in the Deleuzean sense) aesthetics-as the refutation of Greenbergian formalist modernism. ${ }^{68}$ Even when Greenberg was disavowed, he was affirmed. The postmodern "anti-aesthetic," as propounded by Foster in the introductory essay to his highly influential edited volume of the same name, was-despite considering the wider "adventures of the aesthetic" as "one of the great narratives of modernity" (and in the process touching on both Walter Benjamin's and Adorno's work)-ultimately an anti-Greenbergian anti-aesthetic. ${ }^{69}$ In this sense it was also, as Foster reflects in retrospect, “parochial." 70

This anti-aesthetic critical conjuncture has been to the detriment of a more sustained and historically self-reflexive engagement with other accounts of modernism-and indeed of the philosophical critique of (technocratic) modernity more broadly, such as that elaborated by Adorno and Marcuse, as well as the longer German aesthetic tradition, beginning with Schiller's critique of Immanuel Kant, to which these thinkers 
belong. All this has begun to become clear with the waning of the postmodern theory of a French poststructuralist stripe that usurped Greenberg and the concomitant rise of a renewed attention to aesthetics in the theoretical humanities (which has sought to interrogate the philosophical heritage of debates in postmodern theory).${ }^{71}$ Here, Burnham's postformalist, "systems" aesthetics-with its ambition to think the relational ontology of distributed, post-object-specific art in the expanded field and its associated commitment to accounting for the relations between art and technology-finds itself once again "rooted in the present."

1 Patricia Norvell, "Interview with Robert Smithson, June 20, 1969," in Recording Conceptual Art, eds. Alexander Alberro and Patricia Norvell (Berkeley and Los Angeles: University of California Press, 2001), 133.

2 Rosalind Krauss, Passages in Modern Sculpture (Cambridge, MA: MIT Press, 1981), 212; Benjamin Buchloh, “Hans Haacke: The Entwinement of Myth and Enlightenment," in Hans Haacke, "Obra Social" (Barcelona: Fundació Antoni Tàpies, 1995), 49; and Thierry De Duve, Kant after Duchamp, (Cambridge, MA: MIT Press, 1996), 285-86.

3 The series was initiated by Roger Conover in 1991 and publishes the writing of major artists. See https : //mitpress.mit.edu/books/series/writing-art. 4 My list of scholars working on Burnham's work is indicative rather than exhaustive and based on those whose work I have 
engaged with and found most productive. For a regularly updated record of the scholarship on Burnham, see Robert Horvitz's diligently maintained online resource "A Node for Jack Burnham," http://mujweb.cz/horvitz/burnham/homepage.html. For a critical engagement with a selection of the scholarship on Burnham up to 2009, see Edward Shanken, “Reprogramming Systems Aesthetics: A Strategic Historiography," in Proceedings of the 2009 Conference on Digital Arts and Culture (Berkeley and Los Angeles: University of California Press, 2009), http://escholarship.org/uc/item/6bv363d4 .

5 Jack Burnham, Dissolve into Comprehension: Writings and Interviews, 1964-2004, ed. Melissa Ragain (Cambridge, MA: MIT Press, 2015), front cover, inside flap.

6 The phrase originates from Nabokov's 1952 short story "Lance," a sci-fi satire, as Brian Dillon notes in "Present Future," Ruins of the 20th Century [blog], June 18, 2012, https://briangdillon.wordpress.com/2012/06/18/present-future/. 7 A list of Burnham's publications can be found online at Horvitz's website, http://mujweb.cz/horvitz/burnham/homepage.html. A list of Burnham's publications and papers up to 1981 is also available from his CV in Dissolve into Comprehension, 290-96.

${ }^{8}$ Full disclosure: I happily provided an endorsement for the book .

9 On the relationship of the academy to esoteric traditions of thought, see Wouter Hanegraaf, Esotericism and the Academy: 
Rejected Knowledge in Western Culture (Cambridge, MA:

Cambridge University Press, 2014).

10 Jack Burnham, Great Western Salt Works: Essays on the Meaning of Post-formalist Art (New York: George Braziller, $1974), 11$

11 Burnham, Great Western Salt Works, 11.

12 Burnham, Great Western Salt Works, 11.

13 Burnham, Great Western Salt Works, 12.

14 Michel Foucault, Madness and Civilization: A History of Insanity in the Age of Reason (London: Routledge, 2001), 101. 15 Melissa Ragain, "Introduction" in Burnham, Dissolve into Comprehension, xiii.

16 Burnham's training as an engineer is also noted by Courtney Fiske in her article in this issue of Grey Room.

17 See, Benjamin Buchloh, "Cold War Constructivism," in Formalism and Historicity: Models and Methods in TwentiethCentury Art (Cambridge, MA: MIT Press, 2015), 375-408. 18 "Joan Brigham Interviews Jack Burnham," in Dissolve into Comprehension, 244 .

19 "Joan Brigham Interviews Jack Burnham," 244.

20 "Joan Brigham Interviews Jack Burnham," 244.

21 Burnham reflects on the fraught editorial politics of the New York magazines of the period in his article "Criticism in the Provinces" (1978), in Dissolve into Comprehension, 237-40. 22 Fort Belvoir, established in 1912 as a rifle range and summer camp for engineer troops, was the home of the Army 
Engineer School and remained so until the school's relocation to Fort Leonard Wood in 1980. Whether Burnham's military service was as a result of the draft or was voluntary is unclear, but the latter seems more likely given that few Americans were compulsorily inducted in 1949, despite a new compulsory draft having been authorized by the Selective Service Act of 1948, because of the number of servicemen still available following the demobilization after WWII. ${ }^{23}$ The backdrop to this shift in foreign policy was the breakdown of the uneasy alliance between the USSR and the West after the defeat of the Axis powers at the conclusion of WWII. For an account of the Truman Doctrine in its historical context, see Perry Anderson, American Foreign Policy and Its Thinkers (London: Verso, 2014), 29-32. Burnham was posted to Okinawa and New York City during his time as a serviceman. ${ }^{24}$ Caroline A. Jones, Eyesight Alone: Clement Greenberg's Modernism and the Bureaucratization of the Senses (Chicago: University of Chicago Press, 2005).

25 “Joan Brigham Interviews Jack Burnham," 241, 244. 26 Jack Burnham, "Art and Technology: The Panacea That Failed," in The Myths of Information: Technology and Postindustrial Culture, ed. Kathleen Woodward (Madison, WI: Coda Press, $1980), 208$.

27 "Joan Brigham Interviews Jack Burnham," 243.

28 “Joan Brigham Interviews Jack Burnham," 241, 244.

29 "Joan Brigham Interviews Jack Burnham," 241. 
30 Burnham's artistic career began with incandescent light construction in 1954, moved on to constructions with neon tubing in 1955, programmed light environments in 1959, programmed luminous constructions in 1962, and programmed light boxes with fiber-optic wires and chemical filters in 1964, before first using Sylvania tape in 1966. This schematization of Burnham's practice comes from his CV in Burnham, Dissolve into Comprehension, 284.

31 Jack Burnham, Beyond Modern Sculpture: The Effects of Science and Technology on the Sculpture of This Century (New York: George Braziller, 1968), 302.

32 Burnham, "Joan Brigham Interviews Jack Burnham," 244.

33 Jack Burnham, "Steps in the Formulation of Real-Time Political Art," in Hans Haacke, Framing and Being Framed (New York: New York University Press, 1975), 132-33.

34 Ragain derives this claim from a letter from Philip Leider to Michael Fried in which Leider relates his editorial intervention, among other matters. Ragain, "Introduction", xvii-xix.

35 Jack Burnham, "Systems Esthetics," in Great Western Salt Works, 16-17.

36 I discuss Burnham's systems essays at greater length in Luke Skrebowski, “The Artist as Homo Arbiter Formae: Art and Interaction in Jack Burnham's Systems Essays," in Practicable: From Participation to Interaction in Contemporary Art, ed. Samuel Bianchini and Erik Verhagen (Cambridge, MA: MIT Press, 
forthcoming), 39-54. Arguments I make in that text inform my discussion of Art in the Marcusean Analysis and "Systems and Art" in the present article.

37 Jack Burnham, "Systems and Art," Arts in Society 6, no. 2 (Summer/Fall 1969): 194-203. Ragain includes an earlier version of this piece, originally delivered as a lecture, entitled "'Systems and Art': A Post-formalist Design Aesthetic for the Evolving Technology," in Dissolve into Comprehension, 99-108. 38 Burnham, "Systems and Art," 195. Burnham goes on to assert that he "came to realize that most educational approaches to this medium degenerate into technique courses . . and that aesthetic development tends largely to be forgotten" (195). 39 Burnham, "Systems and Art," 195. 40 Burnham, "Systems and Art," 196. 41 Burnham, "Systems and Art," 197. 42 Burnham, "Systems Esthetics," 16. 43 The text was originally written as a lecture in September 1968 but was not presented until January 1969 at Pennsylvania State University. Subsequently it was published as a pamphlet, the sixth volume in the Penn State Papers in Art Education series, also in 1969.

${ }^{44}$ For the only exception I am aware of to this general oversight (of which my own earlier work is also guilty), see Michael Corris, ed., Conceptual Art: Theory, Myth, Practice (Cambridge, UK: Cambridge University Press, 2004), 195, 271. Burnham himself had effectively encouraged such oversight by 
not acknowledging the philosopher's influence on "Systems Esthetics," despite the fact that the article was published in September 1968 and was thus contemporaneous with the composition, if not the delivery, of his lecture on Marcuse and demonstrably indebted to it. Burnham references Marcuse in "Real Time Systems," but the reference is to Eros and Civilization: A Philosophical Inquiry into Freud (1955) and does not touch on his more significant debt to One-Dimensional Man: Studies in the Ideology of Advanced Industrial Society (1964). Burnham also quotes Marcuse on the back jacket of Beyond Modern Sculpture, but not inside, suggesting that he began reading Marcuse after the main text was completed in 1967.

45 Burnham's interpretation of Marcuse concentrates on his One Dimensional Man and "Art in the One-Dimensional Society" (1967). Burnham's analysis also broaches Marcuse's earlier works Eros and Civilization and Soviet Marxism: A Critical Analysis (1961).

46 Jack Burnham, Art in the Marcusean Analysis (Pennsylvania: Pennsylvania State University Press, 1969), 3; emphasis added. 47 Burnham, Art in the Marcusean Analysis, 7-8.

48 Burnham, Art in the Marcusean Analysis, 9.

49 Burnham, Art in the Marcusean Analysis, 8-9.

50 Herbert Marcuse, "Art as a Form of Reality," in On the Future of Art, ed. Edward Fry (New York: The Viking Press, $1970), 133$. 
51 J. Jesse Ramirez productively insists on Marcuse's U.S.specific development of his own "heretical" strand of Frankfurt School thought, elaborated in dialogue with Left Technocracy: “The Left Technocrats' analysis posited that the Machine Age had set in motion processes whose logical conclusion would be a rupture in the economic mode of production. When intellectual historians and critical theorists overlook Marcuse's differences with Horkheimer, Adorno, and Pollock on the issues of automation and economic production, they lump them all together in a tale of the 'Frankfurt School theorists' (in the abstract plural) who abandoned Marxian immanent critique for the dialectic of enlightenment thesis. . . However, it was precisely Marcuse's affinities with the discourse of Left Technocracy that opened up for him a vision of how the dialectic could once again reverse its course. In 'Some Social Implications of Modern Technology' (1941), his first essay in English, Marcuse drew on Mumford's Technics and Civilization (1934) and glimpsed the possibility that the very forces that had so thoroughly rationalized capitalism could trigger a dialectical switch, leading to full automation, radically reduced labor time, the elimination of scarcity, and a true break in the history of civilization and human nature." J. Jesse Ramirez, “Marcuse among the Technocrats: America, Automation, and Postcapitalist Utopias, 1900-1941," Amerikastudien / American Studies 57, no. 1 (2012): 34-35. For recent attempts to think 
about the possibility of a postcapitalist mode of production against the neoliberal boosterism of the technocrats of the second machine age, see, Nick Srnicek and Alex Williams, Inventing the Future: Postcapitalism and a World without Work (London: Verso, 2015) and Paul Mason, Postcapitalism: A Guide to Our Future (London: Allen Lane, 2015).

52 Jack Burnham, "Notes on Art and Information Processing," in Software-Information Technology: Its New Meaning for Art (New York: Jewish Museum, 1970), 14.

53 I discuss this exchange in more detail in Luke Skrebowski, "All Systems Go: Recovering Hans Haacke's Systems Art," Grey Room 30 (2008): 54-83.

54 Jack Burnham, "Jack Burnham, Terry Fenton: An Exchange," Artforum, April 1969, 60; emphasis added.

55 Burnham, "Notes on Art and Information Processing," 14.

56 Burnham, Dissolve into Comprehension, 255-56.

57 Jack Burnham, The Structure of Art (New York: George Braziller, 1971), 7 .

58 For an example of this genre of his work, see Burnham's article on Robert Morris. Jack Burnham, "Voices from the Gate" (1969), in Great Western Salt Works, 119-24.

59 Burnham, "Art and Technology," 200.

60 Burnham, “Art and Technology," 200-201.

${ }^{61}$ Burnham, “Art and Technology," 211-12. 
${ }^{62}$ Martin Heidegger, "The Question Concerning Technology," in Basic Writings of Martin Heidegger, trans. D.F. Krell (London: Routledge, 1977 ), 307-42.

${ }^{63}$ Burnham, "Art and Technology," 214.

64 Burnham, "Art and Technology," 215.

65 Hans Haacke, preface to Dissolve into Comprehension, $\mathrm{x}$.

${ }^{66}$ Mel Ramsden, discussing conceptual art's effect on Greenbergian formalism, refers to “Modernism's nervous breakdown." Mel Ramsden, cited in Charles Harrison, Conceptual Art and Painting: Further Essays on Art and Language (Cambridge, MA: MIT Press, 2001), 27.

${ }^{67}$ See Peter Osborne, "Aesthetic Autonomy and the Crisis of Theory: Greenberg, Adorno, and the Problem of Postmodernism in the Visual Arts," New Formations 9 (Winter 1989): 31-50; and Caroline Jones, “Postmodernism's Greenberg," in Eyesight Alone, 347-86. Foster states, "It's true: the version of postmodernism presented by the nefarious October group was an attempt to break with one model of Modernism, that associated with Greenberg above all others, but also to recover other models, ones displaced by the prestige of Greenberg." See James Elkins and Harper Montgomery, eds., Beyond the Aesthetic and the Anti-Aesthetic (University Park: Pennsylvania State University Press, 2013), 27 .

68 For treatments of Cage's significance and influence, see Branden W. Joseph, Beyond the Dream Syndicate: Tony Conrad and the Arts after Cage: A "Minor" History (New York: Zone, 2008); 
and Liz Kotz, "Post-Cagean Aesthetics and the Event Score," in Words to Be Looked At: Language in 1960s Art (Cambridge, MA: MIT Press, 2007), 59-98.

${ }^{69}$ Hal Foster, "Introduction," in The Anti-aesthetic: Essays on Postmodern Culture, ed. Hal Foster (New York: New Press, 1998), xvii.

70 Elkins and Montgomery, 49.

71 See, for example, Elkins and Montgomery's recent anthology, as well as Armen Avanessian and Luke Skrebowski, eds., Aesthetics and Contemporary Art (Berlin: Sternberg, 2011); and Francis Halsall, Julia Jansen, and Tony O'Connor, Rediscovering Aesthetics: Transdisciplinary Voices from Art History, Philosophy, and Art Practice (Stanford, CA: Stanford University Press, 2009). 